\title{
Qualification evaluation of the results of teachers' professional development which work in the professional (vocational) education institutions
}

\author{
Sysko N.* \\ Ivan Zyazyun Institute of Pedagogical and Adult Education NAES of Ukraine, Kyiv, Ukraine
}

Received: 24.12.2018 Accepted: 27.12.2018

\begin{abstract}
The author of this article considers the problem of qualification evaluation of the results of teachers' professional development which work in the professional (vocational) education institutions. It was analyzed that the procedure of attestation of pedagogical workers is normalized. It was established that in 1993 and in 2010, by the orders of the Ministry of Education and Science of Ukraine, the Model Regulations for the certification of pedagogical workers were approved. Comparison of qualification requirements for dynamics teachers, which are specified in the Model Regulations. The algorithm of attestation procedure is presented. It was established that with the change of socio-economic conditions qualification requirements for teachers of professional (vocational) education institutions were changed in our country. It is revealed that the certification criteria apply to teachers of all types of educational institutions: pre-school, school, vocational and higher education institutions of the I-II level of accreditation. It was emphasized that at this stage of education reform in Ukraine a new form of independent external evaluation of professional competence of teachers is emerging - certification. It was emphasized that it is important to study the positive international experience regarding the certification of teachers and their consideration when developing the Regulations on the certification of Ukrainian pedagogical staff. It has been established that at the transitional stage, the certification procedure will be voluntary. The comprehensive assessment of the teachers' professional competence at the national level is planned to be carried out by the Ukrainian Center for Education Quality Assessment through external independent evaluation (testing) and at the regional level by studying the experience gained. It is emphasized that vocational education is a more complex educational system, because it is directly related to production, the teacher of the professional (vocational) education institutions should have full knowledge of the psychological and pedagogical component of professional activity, and have a high level of technological and production skills. It is emphasized that qualification assessment is a separate important component of the system of continuous professional development. It has been established that the qualification of teachers of the professional (vocational) education institutions requires the development of a special tool that would correspond to the profile of the teacher's professional and pedagogical activity, which is determined by the prospect of further exploration.

Key words: professional development, qualification assessment, attestation, certification, teacher, institution of professional (vocational) education.
\end{abstract}

\section{Кваліфікаційне оцінювання результатів професійного розвитку викладачів закладів професійної (професійно-технічної) освіти}

Сиско Н. М.

\author{
Інституту педагогічної освіти і освіти дорослих імені Івана Зязюна НАПН України, Київ, Україна
}

\begin{abstract}
Анотація. Автором статті розглянуто проблему кваліфікаційного оцінювання результатів професійного розвитку викладачів закладів професійної (професійно-технічної) освіти. Проаналізовано, що процедура атестації педагогічних працівників є унормованою. Встановлено, що у 1993 році і у 2010 році наказами Міністерства освіти і науки України були затверджені Типові положення щодо атестації педагогічних працівників. Здійснено порівняння кваліфікаційних вимог до викладачів у динаміці, які зазначені у Типових положеннях. Наведено алгоритм атестаційної процедури. Встановлено, що зі зміною соціально-економічних умов в державі змінювались кваліфікаційні вимоги до викладачів закладів професійної (професійно-технічної)
\end{abstract}

Corresponding Author: Sysko Nataliia Mukolaivna. Tel. 067-2-756-756. E-mail: nnsysko@ukr.net Ivan Zyazyun Institute of Pedagogical and Adult Education NAES of Ukraine, Maxim Berlinsky str., 9, Kiev, Ukraine, 04060.

Відповідальний автор: Сиско Наталія Миколаївна. Тел. 067-2-756-756. E-mail: nnsysko@ukr.net Інститут педагогічної освіти і освіти дорослих імені Івана Зязюна НАПН України, вул. Максима Берлінського, 9 , Київ, Україна, 04060. 
освіти. З'ясовано, що при атестації застосовуються єдині критеріальні показники для викладачів усіх типів навчальних закладів: дошкільної, шкільної, професійно-технічної освіти та ВНЗ І-ІІ рівня акредитації. Наголошено, що на даному етапі рефрормування освіти в Україні зароджується нова форма незалежного зовнішнього оцінювання професійної компетентності педагогів - сертифікація. Встановлено, що на перехідному етапі процедура сертифікації буде добровільною. Комплексне оцінювання професійної компетентності викладачів на загальнодержавному рівні планується здійснювати Українським центром оцінювання якості освіти шляхом зовнішнього незалежного оцінювання (тестування) та на регіональному рівні шляхом вивчення набутого досвіду. Наголошено, що профресійна освіта $є$ більш складною освітньою системою, оскільки безпосередньо пов'язана з виробництвом, викладач закладу професійної (професійнотехнічної) освіти повинен володіти повною мірою як психолого-педагогічною складовою професійної діяльності, так і мати високий рівень технологічних, виробничих умінь. Підкреслено потребу у розробці професійно-педагогічного профілю викладача закладу професійної (професійно-технічної) освіти та спеціального інструментарію для кваліфікаційної оцінки результатів його професійного розвитку.

Ключові слова: професійний розвиток, кваліфікаційне оцінювання, атестація, сертифікація, викладач, заклад професійної (професійно-технічної) освіти.

\title{
Квалификационное оценивание результатов профессионального развития преподавателей учреждений профессионального (профессионально-технического) образования
}

\author{
Сыско Н. Н. \\ Институт педагогического образования и образования взрослых имени Ивана Зязюна, Киев, Украина
}

\begin{abstract}
Аннотация. Автором статьи рассмотрена проблема квалификационной оценки результатов профессионального развития преподавателей учреждений профессионального (профрессиональнотехнического) образования. Проанализировано, что процедура аттестации педагогических работников нормирована. Установлено, что в 1993 году и в 2010 году приказами Министерства образования и науки Украины были утверждены Типовые положения аттестации педагогических работников. Проведено сравнение квалификационных требований к преподавателям в динамике, которые указаны в Типовых положениях. Приведен алгоритм аттестационной процедуры. Установлено, что с изменением социальноэкономических условий в стране менялись квалификационные требования к преподавателям учреждений профессионального (профессионально-технического) образования. Выяснено, что при аттестации применяются единые критериальные показатели для преподавателей всех типов учебных заведений: дошкольного, школьного, профессионально-технического образования и вузов I-ІІ уровня аккредитации. Отмечено, что на данном этапе реформирования образования в Украине зарождается новая форма независимого внешнего оценивания профессиональной компетентности педагогов - сертификация. Установлено, что на переходном этапе процедура сертификации будет добровольной. Комплексную оценку профессиональной компетентности преподавателей на общегосударственном уровне планируется осуществлять Украинским центром оценивания качества образования путем внешнего независимого оценивания (тестирования) и на региональном уровне путем изучения накопленного опыта. Отмечено, что профрессиональное образование является более сложной образовательной системой, поскольку непосредственно связано с производством, преподаватель учреждения профрессионального (профессионально-технического) образования должен обладать в полной мере как психолого-педагогической составляющей профессиональной деятельности, так и иметь высокий уровень технологических, производственных умений. Подчеркнута потребность в разработке профрессионально-педагогического профиля преподавателя учреждения профессионального (профессионально-технического) образования и специального инструментария для квалификационной оценки результатов его профрессионального развития. Ключевые слова: развитие, квалификационная оценка, аттестация, сертификация, преподаватель, заведение профессионального (професссионально-технического) образования.
\end{abstract}

\section{Bcmyn}

Однією зі складових системи неперервного професійного розвитку викладачів закладів професійної (професійно-технічної) освіти $€$ інституція, яка здійснює кваліфікаційне оцінювання результатів професійно-педагогічної діяльності педагогів, що безпосередньо пов'язуєтеся з якістю освіти.

Закон України “Про освіту” у розділі “Забезпечення якості освіти” запроваджує нові норми щодо інституцій, які мають вплив на професійний розвиток педагогічних працівників та оцінювання результатів їх діяльності [3], а отже, на продуктивність та якість педагогічної діяльності. Зокрема, ст. 41 
"Система забезпечення якості" визначає, що їі складовими є внутрішня система забезпечення якості та зовнішня система забезпечення якості.

Внутрішня система забезпечення якості функціонує безпосередньо у навчальному закладі, одним із завдань якої $\epsilon$ оцінювання педагогічної діяльності педагогічних працівників за певними оприлюдненими критеріями, правилами та процедурами. Мова йде про оцінювання педагогічної діяльності, а ось кваліфікаційна атестація та сертифікація педагогів, відповідно до Закону, повинна здійснюватися інституціями системи зовнішнього забезпечення якості освіти.

Отже, концептуально в освіті України запроваджується незалежне зовнішнє оцінювання діяльності педагогічних працівників, зокрема, викладачів закладів професійної (професійно-технічної) освіти, кваліфікаційне оцінювання результатів їх професійного розвитку.

Атестація і сертифрікація педагогічних працівників стають зовнішніми мотиваційними чинниками профресійного розвитку викладачів, одним з найважливіших елементів кадрової роботи та представляє собою періодичний огляд професійної придатності, відповідності займаній посаді, визначення кваліфікаційного статусу педагога.

Мета роботи: здійснення аналізу кваліфікаційного оцінювання професійного розвитку викладачів закладів професійної (професійно-технічної) освіти та його ролі у професійному зростанні педагога.

\section{II Матеріал і методи дослідження}

Поняття "атестація", яке походить з лат. attestation (посвідчення підтвердження), словник іншомовних слів трактує як "визначення кваліфікації працівника, відзив про його здібності, ділові та інші якості" [10, с.76].

у "Термінологічному словнику з основ підготовки наукових та науково-педагогічних кадрів післядипломної педагогічної освіти" атестація визначається як процес оцінювання виконання працівником посадових обов'язків, визначення кваліфрікації працівника, відгук про його здібності, ділові та інші якості [11].

У Законі України “Про освіту" у статті 50 "Атестація педагогічних працівників" визначено, що “це система заходів, спрямованих на всебічне та комплексне оцінювання педагогічної діяльності педагогічних працівників" [3].

Атестація педагогічних працівників передбачає наявність завчасно розроблених параметрів оцінки їх кваліфікації та відбувається як формалізоване оцінювання, що проводиться у певний час, у встановленій формі за спеціально розробленою процедурою, за результатами якої приймаються рішення щодо професійно-кваліфікаційного просування педагога.

Енциклопедія освіти атестацію педагогічних кадрів трактує як державне визначення кваліфікації спеціаліста, рівня його професійних знань, практичного досвіду, необхідних для виконання службових обов'язків, визначення відповідності займаній посаді, рівню кваліфікації [2].

Отже, атестація - це комплексне оцінювання рівня кваліфікації педагогічного професіоналізму, продуктивності і результативності діяльності викладача закладу професійної (профресійно-технічної) освіти.

Проведення атестації стимулює професійний і особистісний розвиток педагога, сприяє підвищенню його особистого внеску в досягнення результатів роботи навчального закладу.

Варто зазначити, що вперше атестація, як нова правова норма, з'явилась у 1974 році. Дана процедура була зумовлена розширенням мережі закладів професійно-технічної освіти, збільшенням кількості педагогічних працівників в ній, загостреною потребою контролю за розвитком професіоналізму педагогів, відповідності займаній посаді та станом оволодіння ними сучасними педагогічними і інженерно-технічними знаннями, технологіями. Умови атестації педагогічних працівників та їі періодичність раз у п'ять років сприяли значному підвищенню відповідальності педагогічних кадрів за особистий рівень професіоналізму і якості навчально-виховної діяльності, що в цілому позитивно відображалось на підвищенні навчально-виховного потенціалу навчального закладу [1].

Наступний період розвитку України як незалежної держави зумовив потребу у впровадженні національних підходів до кваліфікаційного оцінювання педагогів. У 1993 році з метою активізації творчої діяльності, стимулювання неперервної фахової та загальної освіти педагогічних працівників, підвищення їх персональної відповідальності за результати навчання та виховання дітей та молоді було 
затверджено та введено в дію Типове положення про атестацію педагогічних працівників України (далі Положення), затверджене наказом Міністерства освіти України № 310 від 20 серпня 1993 року [12], яке поширювалось на усі категорії педагогічних працівників різних типів закладів системи середньої освіти, професійно-технічної освіти та вищих навчальних закладів I-ІІ рівнів акредитації.

У той історичний період атестація педагогічних працівників розглядалась як процедура визначення їх відповідності займаній посаді, рівню кваліфікації, залежно від яких та стажу педагогічної роботи педпрацівникам встановлювалась кваліфікаційна категорія та відповідний посадовий оклад.

Цим Положенням [12] були проголошені принципи атестації: демократизм, загальність, всебічність, систематичність, колегіальність, доступність та гласність, безперервність освіти і самовдосконалення, моральне та матеріальне заохочення. Атестація передбачала комплексну оцінку рівня кваліфікації педагогічної майстерності, результатів педагогічної діяльності викладачів.

У Положенні зазначалось, що комплексна оцінка результатів діяльності педпрацівника повинна здійснюватися шляхом проведення контрольних робіт, "зрізів знань учнів", тестування, а також відвідування уроків, позакласних заходів, здійснення аналізу освітнього процесу з урахуванням думки батьків, учнів.

Нове Типове положення про атестацію педагогічних працівників було прийнято у 2010 році (наказ МOH України № 930 від 06.10.2010 року) та доповнене у 2011 р. (наказ МОНмолодьспорт № 1473) i 2013 році (наказ МОН №1135). Доповнення вносились відповідно до змін у системі освіти України.

Положення визначає, що атестація педагогічних працівників - це система заходів, що спрямована на всебічне комплексне оцінювання їх педагогічної діяльності, за якою визначаються відповідність педагогічного працівника займаній посаді, рівень його кваліфікації, присвоюється кваліфікаційна категорія, педагогічне звання [13].

Метою атестації визначено стимулювання цілеспрямованого безперервного підвищення рівня професійної компетентності педагогічних працівників, росту їх професійної майстерності, розвитку творчої ініціативи, підвищення престижу й авторитету, забезпечення ефективності навчально-виховного процесу.

Основними принципами атестації визначено відкритість та колегіальність, гуманне та доброзичливе ставлення до педагогічного працівника, повнота, об'єктивність та системність оцінювання його педагогічної діяльності [13].

У новому положенні змінено критерії оцінювання професіоналізму педагогів на підставі аналізу їх діяльності, унормовано послідовність їх кваліфікаційної атестації. Динаміку зміни кваліфікаційних вимог до викладачів представлено у таблиці 1.

Табл. 1. Динаміка зміни кваліфікаційних вимог до викладачів

\begin{tabular}{|c|c|c|}
\hline $\begin{array}{c}\text { Кваліфікаційна } \\
\text { категорія, } \\
\text { педагогічне звання }\end{array}$ & $\begin{array}{c}\text { Типове положення } \\
\text { про атестацію педагогічних працівників } \\
\text { України } 1993 \text { року } \\
\text { (зі змінам } 1998 \text { р.) }\end{array}$ & $\begin{array}{c}\text { Типове положення } \\
\text { про атестацію педагогічних працівників } \\
2010 \text { року } \\
\text { (зі змінам } 2011 \text { р.,2013р.) }\end{array}$ \\
\hline "Спеціаліст" & $\begin{array}{l}\text { Підтверджується викладачам, які } \\
\text { професійно компетентні, забезпечують } \\
\text { нормативні рівні і стандарти навчання } \\
\text { та виховання. }\end{array}$ & $\begin{array}{l}\text { Присвоюється викладачам з повною } \\
\text { вищою освітою, діяльність яких } \\
\text { характеризується: здатністю } \\
\text { забезпечувати засвоєння учнями } \\
\text { навчальних програм; знанням основ } \\
\text { педагогіки, психології, дитячої та вікової } \\
\text { фізіології; знанням теоретичних основ } \\
\text { та сучасних досягнень науки з } \\
\text { предмета, який вони викладають; } \\
\text { використанням інфрормаційно- } \\
\text { комунікаційних технологій, цифрових } \\
\text { освітніх ресурсів у навчально- } \\
\text { виховному процесі; вмінням вирішувати } \\
\text { педагогічні проблеми; вмінням }\end{array}$ \\
\hline
\end{tabular}




\begin{tabular}{|c|c|c|}
\hline $\begin{array}{c}\text { Кваліфікаційна } \\
\text { категорія, } \\
\text { педагогічне звання }\end{array}$ & $\begin{array}{c}\text { Типове положення } \\
\text { про атестацію педагогічних працівників } \\
\text { України } 1993 \text { року } \\
\text { (зі змінам } 1998 \text { р.) } \\
\end{array}$ & $\begin{array}{c}\text { Типове положення } \\
\text { про атестацію педагогічних працівників } \\
2010 \text { року } \\
\text { (зі змінам } 2011 \text { р.,2013р.) } \\
\end{array}$ \\
\hline & & $\begin{array}{l}\text { установлювати контакт з учнями } \\
\text { (вихованцями), батьками, колегами по } \\
\text { роботі; додержанням педагогічної } \\
\text { етики, моралі. Встановлюється при } \\
\text { прийнятті на посаду. }\end{array}$ \\
\hline $\begin{array}{l}\text { "Спеціаліст } \\
\text { другої } \\
\text { категорії” }\end{array}$ & $\begin{array}{l}\text { Встановлюється педагогічним } \\
\text { працівникам, які виявили достатній } \\
\text { рівень професіоналізму, } \\
\text { використовують сучасні фоорми і } \\
\text { методи навчання та виховання, } \\
\text { досягли вагомих результатів у } \\
\text { педагогічній діяльності. } \\
\text { Стаж безпосередньої педагогічної } \\
\text { роботи не менше } 3 \text { років. }\end{array}$ & $\begin{array}{l}\text { Присвоюється викладачам, які } \\
\text { відповідають вимогам, встановленим } \\
\text { до працівників з кваліфрікаційною } \\
\text { категорією “спеціаліст”, та які постійно } \\
\text { вдосконалюють свій професійний } \\
\text { рівень; використовують } \\
\text { диференційований та індивідуальний } \\
\text { підхід до учнів; володіють сучасними } \\
\text { освітніми технологіями, методичними } \\
\text { прийомами, педагогічними засобами, } \\
\text { різними фрормами позаурочної } \\
\text { (позанавчальної) роботи та їх якісним } \\
\text { застосуванням; застосовують } \\
\text { інноваційні технології у навчально- } \\
\text { виховному процесі; знають основні } \\
\text { нормативно-правові акти у галузі } \\
\text { освіти; користуються авторитетом } \\
\text { серед колег, учнів та їх батьків. } \\
\text { Стаж роботи не менше } 2 \text { років. }\end{array}$ \\
\hline $\begin{array}{l}\text { "Спеціаліст } \\
\text { першої } \\
\text { категорії" }\end{array}$ & $\begin{array}{l}\text { Встановлюється викладачам, які } \\
\text { виявили ґрунтовний рівень } \\
\text { професіоналізму, добре володіють } \\
\text { ефективними формами і методами } \\
\text { педагогічної діяльності, досягли } \\
\text { значних результатів у вирішенні } \\
\text { навчально-виховних завдань. } \\
\text { Стаж безпосередньої педагогічної } \\
\text { роботи не менше } 5 \text { років. }\end{array}$ & $\begin{array}{l}\text { Присвоюється викладачам, які } \\
\text { відповідають вимогам, встановленим } \\
\text { до працівників з кваліфрікаційною } \\
\text { категорією “спеціаліст другої категорії”, } \\
\text { та які використовують методи } \\
\text { компетентнісно-орієнтованого підходу } \\
\text { до організації навчального процесу; } \\
\text { володіють технологіями творчої } \\
\text { педагогічної діяльності з урахуванням } \\
\text { особливостей навчального матеріалу і } \\
\text { здібностей учнів; впроваджують } \\
\text { передовий педагогічний досвід; } \\
\text { формують навички самостійно } \\
\text { здобувати знання й застосовувати їх на } \\
\text { практиці; уміють лаконічно, образно і } \\
\text { виразно подати матеріал; вміють } \\
\text { аргументувати свою позицію та } \\
\text { володіють ораторським мистецтвом. } \\
\text { Стаж роботи не менше } 5 \text { років. }\end{array}$ \\
\hline $\begin{array}{l}\text { “Спеціаліст } \\
\text { вищої категорії” }\end{array}$ & $\begin{array}{l}\text { Встановлюється педагогічним } \\
\text { працівникам, які виявили високий } \\
\text { рівень професіоналізму, ініціативи, } \\
\text { творчості, досконало володіють } \\
\text { ефрективними фрормами і методами }\end{array}$ & $\begin{array}{l}\text { Присвоюється працівникам, які } \\
\text { відповідають вимогам, встановленим } \\
\text { до працівників з кваліфікаційною } \\
\text { категорією “спеціаліст першої } \\
\text { категорії”, та які володіють }\end{array}$ \\
\hline
\end{tabular}




\begin{tabular}{|c|c|c|}
\hline $\begin{array}{c}\text { Кваліфікаційна } \\
\text { категорія, } \\
\text { педагогічне звання }\end{array}$ & $\begin{array}{c}\text { Типове положення } \\
\text { про атестацію педагогічних працівників } \\
\text { України } 1993 \text { року } \\
\text { (зі змінам } 1998 \text { р.) } \\
\end{array}$ & $\begin{array}{c}\text { Типове положення } \\
\text { про атестацію педагогічних працівників } \\
2010 \text { року } \\
\text { (зі змінам } 2011 \text { р.,2013р.) } \\
\end{array}$ \\
\hline & $\begin{array}{l}\text { організації навчально-виховного } \\
\text { процесу, забезпечують високу } \\
\text { результативність, якість своєї праці. } \\
\text { Стаж безпосередньої педагогічної } \\
\text { роботи не менше } 8 \text { років .Як виняток } \\
\text { цей стаж може бути скорочений до } 5 \\
\text { років. Для педагогічних працівників } 3 \\
\text { вченими званнями та науковими } \\
\text { ступенями враховується стаж їх } \\
\text { безпосередньої педагогічної роботи у } \\
\text { вищому навчальному закладі. }\end{array}$ & $\begin{array}{l}\text { інноваційними освітніми методиками й } \\
\text { технологіями, активно їх } \\
\text { використовують та поширюють у } \\
\text { професійному середовищі; володіють } \\
\text { широким спектром стратегій навчання; } \\
\text { вміють продукувати оригінальні, } \\
\text { інноваційні ідеї; застосовують } \\
\text { нестандартні форми проведення уроку } \\
\text { (навчальних занять); активно } \\
\text { впроваджують форми та методи } \\
\text { організації навчально-виховного } \\
\text { процесу, що забезпечують } \\
\text { максимальну самостійність навчання } \\
\text { учнів; вносять пропозиції щодо } \\
\text { вдосконалення навчально-виховного } \\
\text { процесу в навчальному закладі. } \\
\text { Стаж роботи не менше } 8 \text { років. }\end{array}$ \\
\hline $\begin{array}{l}\text { "Старший } \\
\text { викладач" }\end{array}$ & $\begin{array}{l}\text { Може присвоюватись викладачам, } \\
\text { яким встановлено кваліфікаційну } \\
\text { категорію “спеціаліст вищої категорії", } \\
\text { "спеціаліст першої категорії”. } \\
\text { Зазначені педагогічні звання } \\
\text { присвоюються педагогічним } \\
\text { працівникам, які досягли високого } \\
\text { професіоналізму в роботі, } \\
\text { систематично використовують } \\
\text { прогресивний педагогічний досвід, } \\
\text { беруть активну участь у його } \\
\text { поширенні, надають практичну } \\
\text { допомогу у становленні молодих } \\
\text { педагогів, постійно працюють над } \\
\text { своїм фраховим самовдосконаленням. }\end{array}$ & $\begin{array}{l}\text { Присвоюється викладачам, які мають } \\
\text { кваліфікаційні категорії “спеціаліст } \\
\text { вищої категорії” або “спеціаліст першої } \\
\text { категоріі” та досягли високого } \\
\text { професіоналізму в роботі, } \\
\text { систематично використовують } \\
\text { передовий педагогічний досвід, беруть } \\
\text { активну участь у його поширенні, } \\
\text { надають практичну допомогу іншим } \\
\text { педагогічним працівникам. }\end{array}$ \\
\hline $\begin{array}{l}\text { "Викладач- } \\
\text { методист" }\end{array}$ & $\begin{array}{l}\text { Присвоюється викладачам, які мають } \\
\text { кваліфрікаційну категорію “спеціаліст } \\
\text { вищої категорії”, відповідають вимогам } \\
\text { для присвоєння звань “старший } \\
\text { викладач", а також запроваджують у } \\
\text { навчально-виховний процес ефективні } \\
\text { форми і методи роботи, узагальнюють } \\
\text { передовий педагогічний досвід, беруть } \\
\text { активну участь у розробленні } \\
\text { шкільного компонента змісту освіти, } \\
\text { діяльності професійних педагогічних } \\
\text { об'єднань, асоціацій, надають } \\
\text { практичну допомогу педагогічним } \\
\text { працівникам інших навчально- } \\
\text { виховних закладів в освоєнні досвіду } \\
\text { провідних педагогів і мають власні }\end{array}$ & $\begin{array}{l}\text { Присвоюється викладачам, які мають } \\
\text { кваліфрікаційну категорію “спеціаліст } \\
\text { вищої категорії”, здійснюють науково- } \\
\text { методичну і науково-дослідну } \\
\text { діяльність, мають власні методичні } \\
\text { розробки, які пройшли апробацію та } \\
\text { схвалені науково-методичними } \\
\text { установами або професійними } \\
\text { об'єднаннями викладачів професійно- } \\
\text { технічних та вищих навчальних } \\
\text { закладів І-ІІ рівнів акредитації, закладів } \\
\text { післядипломної освіти. }\end{array}$ \\
\hline
\end{tabular}




\begin{tabular}{|l|l|c|}
\hline $\begin{array}{c}\text { Кваліфікаційна } \\
\text { категорія, } \\
\text { педагогічне звання }\end{array}$ & \multicolumn{1}{|c|}{$\begin{array}{c}\text { Типове положення } \\
\text { про атестацію педагогічних працівників } \\
\text { України 1993 року } \\
\text { (зі змінам 1998 р.) }\end{array}$} & $\begin{array}{c}\text { Типове положення } \\
\text { про атестацію педагогічних працівників } \\
2010 \text { року }\end{array}$ \\
\hline & $\begin{array}{l}\text { методичні розробки, які пройшли } \\
\text { апробацію та схвалені науково- } \\
\text { методичними установами відповідного } \\
\text { (зінам 2011 р.,2013 р.) }\end{array}$ & \\
&
\end{tabular}

Як видно з порівняльної таблиці, у попередньому Положенні формально проголошувалися рівні профресіоналізму педагогів: достатній, ґрунтовний, високий - без конкретизації показників, що потребувало більш розширеного опису етапів професійного розвитку викладачів та критеріальних показників їх оцінювання.

Отже, аналіз динаміки кваліфікаційних вимог у різні періоди розвитку освіти засвідчує про їх зростання. Виявляється більш чітке визначення показників та компетентностей, якими викладачі повинні володіти відповідно до інноваційного розвитку педагогічної науки.

Разом з тим, варто відзначити, що дані Положення ґрунтуються на єдиних критеріальних показниках для викладачів усіх рівнів освіти та типів навчальних закладів: дошкільної, шкільної, профресійно-технічної та ВНЗ І-ІІ рівня акредитації. Специфріка діяльності викладача закладу професійної (професійно-технічної) освіти є особливим видом педагогічної діяльності, яка полягає у взаємодії педагогічної складової навчального процесу та професійної складової у конкретній виробничій сфері, що й вирізняє діяльність викладачів від інших категорій педагогічних працівників.

У зв'язку з цим, на нашу думку, кваліфікаційне оцінювання рівня професійно-педагогічної компетентності викладачів закладів професійної (професійно-технічної) освіти потребує спеціального інструментарію.

Положенням визначено, що атестація є обов'язковою процедурою, яка може бути черговою (один раз на п'ять років) і позачерговою (через два роки після попередньої). Умовою чергової атестації $\epsilon$ обов'язкове проходження не рідше одного разу на п'ять років підвищення кваліфікації на засадах вільного вибору форм навчання, програм і навчальних закладів [13].

Відповідно до Положення створюються різнорівневі атестаційні комісії.

Атестаційні комісії I рівня створюються у професійно-технічних навчальних закладах, до повноважень яких відноситься атестація педагогічних працівників на відповідність займаній посаді; підтвердження та присвоєння кваліфікаційних категорій "спеціаліст", “спеціаліст другої категоріі”, "спеціаліст першої категорії; порушення клопотання перед атестаційними комісіями II, III рівнів, атестаційними комісіями центральних органів виконавчої влади, яким підпорядковані навчальні заклади, про присвоєння педагогічним працівникам кваліфікаційної категорії "спеціаліст вищої категорії" (про відповідність раніше присвоєній кваліфікаційній категорії “спеціаліст вищої категорії) та про присвоєння педагогічних звань (про відповідність раніше присвоєним педагогічним званням) [13].

Атестаційні комісії II рівня створюються у відділах освіти районних, адміністрацій, інших підрозділах місцевих органів виконавчої влади та виконавчих органів рад, у підпорядкуванні яких перебувають навчальні заклади. До їх повноважень відносяться: присвоєння кваліфікаційних категорій, педагогічних звань педагогічним працівникам навчальних закладів і установ, у яких не створено атестаційні комісії; присвоєння кваліфікаційних категорій “спеціаліст вищої категорії"), присвоєння педагогічних звань за клопотанням атестаційних комісій I рівня; розгляд апеляцій на рішення атестаційних комісій I рівня [13].

Атестаційні комісії III рівня створюються в органах управління освітою обласних, міських державних адміністрацій та мають право: присвоювати кваліфікаційну категорію "спеціаліст вищої категорії, присвоювати педагогічні звання педагогічним працівникам навчальних закладів за клопотанням атестаційних комісій розглядати апеляції на рішення атестаційних комісій I та II рівнів [13].

Організація та строки проведення атестації представлені нами у таблиці 2. 
Табл. 2. Організація та строки проведення атестації педагогічних працівників

\begin{tabular}{|c|c|c|}
\hline № nор. & Процедура & Термін \\
\hline 1. & Створення атестаційних комісій & До 20 вересня \\
\hline 2. & $\begin{array}{l}\text { Створення списків педагогічних працівників, які підлягають } \\
\text { черговій атестацій, прийом заяв від педагогів, які бажають } \\
\text { атестуватись позачергово }\end{array}$ & До 10 жовтня \\
\hline 3 & $\begin{array}{l}\text { Атестаційна комісія затверджує списки педагогічних } \\
\text { працівників, які атестуються, графрік роботи атестаційної } \\
\text { комісії. }\end{array}$ & До 20 жовтня \\
\hline 4. & $\begin{array}{l}\text { Атестаційна комісія відповідно до затвердженого графріка } \\
\text { роботи вивчає педагогічну діяльність педагогів шляхом } \\
\text { відвідування навчальних занять, позанавчальних закладів, } \\
\text { вивчення рівня навчальних досягнень учнів з предмета, що } \\
\text { викладає педагог, його участь у роботі методичних } \\
\text { об'єднань, фахових конкурсах та інших заходах тощо }\end{array}$ & До 15 березня \\
\hline 5. & $\begin{array}{l}\text { Керівник навчального подає до атестаційної комісії } \\
\text { характеристику діяльності педагогічного працівника у } \\
\text { міжатестаційний період }\end{array}$ & До 1 березня \\
\hline 6. & $\begin{array}{l}\text { Атестація педагогічних працівників здійснюється } \\
\text { атестаційними комісіями: } \\
\text { І рівня } \\
\text { II рівня } \\
\text { III рівня }\end{array}$ & $\begin{array}{l}\text { До } 1 \text { квітня } \\
\text { До } 10 \text { квітня } \\
\text { До } 25 \text { квітня }\end{array}$ \\
\hline
\end{tabular}

Атестація на відповідність займаній посаді з присвоєнням кваліфікаційних категорій проводиться щодо викладачів, які мають вищу педагогічну або іншу вищу освіту за освітньо-кваліфікаційним рівнем "спеціаліст", "магістр" і пройшли спеціальну педагогічну підготовку.

Присвоєння кваліфрікаційних категорій за результатами атестації здійснюється послідовно. Виняток становлять викладачі, які у міжатестаційний період підготували переможців всеукраїнських конкурсів фахової майстерності серед учнів професійно-технічних навчальних закладів, переможців всеукраїнського конкурсу - захисту науково-дослідницьких робіт учнів - членів Малої академії наук, а також педагогічні працівники, які стали переможцями або лауреатами конкурсів фахової майстерності, що проводяться центральними органами виконавчої влади, мають наукові ступені, вчені або почесні звання, якщо їх діяльність за профрілем збігається з наявним науковим ступенем, ученим (почесним) званням.

Результати атестації чинні упродовж 5 років. Присвоєні кваліфікаційні категорії та педагогічні звання $€$ підставою для встановлення надбавок до заробітної плати та є матеріальним заохоченням для педагогів до професійного зростання.

Водночас варто зазначити, що дані надбавки до заробітної плати $є$ незначними та складають лише $10 \%$ до посадового окладу від категорії до категорії [3]. Такий стан речей не сприяє зростанню мотивації педагога до власного професійного розвитку, а в цілому - престижності педагогічної праці.

\section{III Результати}

Діюче Положення про атестацію педагогічних працівників вступає в протиріччя з новоприйнятим Законом України "Про освіту", оскільки атестація педагогічних працівників переходить з повноважень навчального закладу до повноважень іншої інституції - зовнішньої системи забезпечення якості освіти. Одночасно з атестацією передбачається добровільна сертифікація педагогічних працівників [3].

Як наголошує В. Лунячек (2017), "на порядок денний виходить питання оцінювання результатів процесу підвищення кваліфікації, що частково передбачатиме зміни в механізмах атестації педагогічних працівників і вплине на процеси їх сертифікації, які тільки починають формуватися" [6]. 
Термін "сертифрікація" - це підтвердження відповідності третьою стороною (особою, яка $є$ незалежною від особи, що надає об'єкт оцінки відповідності, та від особи, що заінтересована в такому об'єкті як споживач чи користувач), яке стосується продукції, процесів, послуг, систем або персоналу" [4].

у "Юридичному словнику" тлумачиться дане поняття так: “Сертифікація - це процедура, за допомогою якої визнаний в установленому порядку орган документально засвідчує відповідність продукції, систем якості, систем управління якістю, систем екологічного управління, персоналу встановленим законодавством вимогам [17].

Отже, сертифікація - це підтвердження третьою, незалежною стороною відповідності викладача вимогам, що встановлені законодавством.

Статтею 51. "Сертифрікація педагогічних працівників" Закону України “Про освіту" визначено, що сертифрікація - це зовнішнє оцінювання професійних компетентностей педагогічного працівника (у тому числі з педагогіки та психології, практичних вмінь застосування сучасних методів і технологій навчання), що здійснюється шляхом незалежного тестування, самооцінювання та вивчення практичного досвіду роботи, що відбувається на добровільних засадах виключно за ініціативою самого педагога [3]. Цією статтею визначено, що процедуру сертифікації педагогічних працівників здійснюють спеціально уповноважені державою установи, Положення про які затверджує Кабінет Міністрів України.

На виконання вимог Закону України «Про освіту» Міністерством освіти і науки України розроблено проекту Положення про сертифікацію педагогічних працівників [8], який запропоновано для громадського обговорення. Положення має врегулювати процедуру оцінювання професійних компетентностей педагогічного працівника шляхом незалежного тестування, самооцінювання та вивчення практичного досвіду його роботи.

Процедура сертифікації, яка планується здійснюватися на добровільних засадах, послугує підвищенню престижності педагогічної праці та заохотить вчителя до особистісного і професійного зростання. За результатами успішного проходження сертифікації педагогічному працівнику видається сертифікат, який $є$ дійсним упродовж трьох років. Успішне проходження сертифікації зараховується як проходження атестації педагогічним працівником та забезпечить встановлення доплати у розмірі $20 \%$ посадового окладу.

Проектом передбачено, що процедура сертифікації буде складатися з таких етапів як оцінювання професійних компетентностей учасників сертифікації шляхом їх незалежного тестування, що організовується Українським центром оцінювання якості освіти та регіональними центрами оцінювання якості освіти, а також вивчення та експертне оцінювання практичного досвіду роботи учасників сертифікації, що організовується Державною службою якості освіти та її територіальними органами [8].

Педагогічні працівники, які пройшли сертифікацію повинні впроваджувати і поширювати методики компетентнісного навчання та нові освітні технології. Вони можуть залучатися до проведення інституційного аудиту в інших закладах освіти, розроблення та акредитації освітніх програм, а також до інших процедур і заходів, пов'язаних із забезпеченням якості та впровадженням інновацій, педагогічних новацій і технологій у системі освіти.

Комплексне оцінювання професійної компетентності викладачів планується проведення шляхом зовнішнього незалежного оцінювання (тестування) на загальнодержавному рівні Українським центром оцінювання якості освіти, а також перевірки методик викладання і знання педагогом вікової психології, вивчення його досвіду на регіональному рівні.

Міністр освіти і науки Л. Гриневич наголошує: "через механізм сертифікації ми хочемо віднайти тих кращих провідників Нової української школи, агентів змін, що готові ділитися та поширювати сучасні методики навчання. Реалізувати таку мету можна лише за умови добровільності процесу, тому ми ретельно слідкуватимемо за дотриманням цього принципу. 2019-го ми обмежили кількість учасників до 1 тис осіб, а також поширили це лише на одну категорію педагогів - вчителів початкових класів. Пілотування сертифікації також продовжиться у 2020 та 2021 роках, я сподіваюся, що в наступні роки ми зможемо розширити і кількість можливих учасників, і категорії вчителів, які зможуть брати участь у сертифрікації" [15]. 


\section{IV Обговорення}

При розробці Положення про сертифікацію педагогічних працівників варто врахувати міжнародний досвід.

О. Огієнко (2016) зауважує, що розвиток систем педагогічної освіти Великої Британії, Канади та США зумовлюється загальними чинниками, такими як: науково-технічний розвиток суспільства, потреба у фахівцях високого професійного рівня для різних галузей економіки, необхідність підвищення якості підготовки педагогічних кадрів, глобалізаційні процеси в освіті, сучасні міжнародні ідеї професіоналізації, інтеграції та універсалізації [7].

Т. Ткачук (2015) зазначає, що процедура сертифікації $€$ поширеною світовою практикою і залежить від системи керування навчальним закладом. При централізованій системі (Норвегія, Японія) учитель не може потрапити у школу, не маючи сертифіката, тому в цих країнах процедура уніфікована. Натомість у лібералізованих системах (Велика Британія, Канада, США) кожна провінція встановлює власні вимоги до тестів для сертифрікації [14].

Федеральна доповідь під назвою "Нація в небезпеці" (“A Nation at Risk”), яка була оприлюднена у 1983 році, стала поштовхом до освітніх реформ у США та розробки національних стандартів педагогічної освіти [18; 20].

У 1987 р. було створено Національну раду професійних педагогічних стандартів (The National Board for Professional Teaching Standards) - незалежну, неурядову організацію, головною метою якої була розробка й адміністрування системи передової професійної сертифікації вчителів [5].

Атестація та сертифікація вчителів у США, спрямована на приведення системи освіти у відповідність із побажаннями суспільства, є одним зі способів досягнення цілей підготовки покоління людей постіндустріального століття [5].

На сьогодні в США створено національні вимірювальні програми (NES), які дають змогу в режимі он-лайн скласти тест на потенційні педагогічні здібності. Американський учитель, який хоче отримувати вищу зарплату, може звернутися в Національну Раду Професійних Учительських Стандартів (National Board for Professional Teaching Standards), і якщо успішно складе іспити, то отримає загальнонаціональну ліцензію, яка даватиме змогу працювати в будь-якому штаті США [14].

Також для удосконалення навчального процесу й забезпечення підвищення кваліфікації вчителів у країні працюють інші національні організації: Національна рада з акредитації педагогічної освіти (National Council for Accreditation of Teacher Education) та міжштатний Консорціум підтримки й оцінювання молодих учителів (Interstate New Teacher Assessment and Support Consortium), Рада директорів державних шкіл (Council of Chief State School Officers), профспілки вчителів: Національна асоціація Освіти (National Education Association) і Американська фредерація вчителів (American Federation of Teachers) та інші федеральні організації [19, с. 119-120].

Варто відзначити, що одним із головних пріоритетів освітніх реформ у США $є$ педагогічна компетентність педагогів, оскільки сучасні педагоги складають важливу групу інтелігенції, здатну істотно впливати не лише на соціалізацію учнів (мікрорівень), а й на розвиток спільноти загалом (макрорівень) [18].

Водночас, ми погоджуємось з Л. Шевчук (2016), яка наголошує, що профресійна освіта є більш складною освітньою системою, оскільки безпосередньо пов'язана з виробництвом. Педагогічний персонал повинен володіти повною мірою як психолого-педагогічною складовою професійної діяльності, так і мати високий рівень технологічних, виробничих умінь, аби засобами своєї спеціальності вміло формувати висококваліфікованого, соціально відповідального фахівця [16].

Профресійно (професійно-технічна) освіта потребує інноваційного педагога, який здатен до розробки та впровадження авторських навчальних програм, проектів, освітніх методик і технологій, методів і засобів навчання, спрямованих на оволодіння учнями виробничими компетентностями в обраній професії.

Практика засвідчує, що високопрофесійні викладачі залучаються до розробки державних стандартів з професійної (професійно-технічної) освіти, $€$ авторами посібників і підручників. Це підтверджується їхнім правом на педагогічну ініціативу, академічну свободу, а також справедливе та об'єктивне оцінювання професійної діяльності. 
Оцінюючи рівень кваліфікації педагогів системи професійної освіти, необхідно враховувати рівень їх професійної компетентності в змісті навчального предмета, професії, а також рівень психологопедагогічної, методичної, навчально-виховної, творчої, експериментальної й організаційної компетентностей у педагогічній діяльності [16].

3 метою запровадження кваліфікаційного оцінювання викладачів закладів професійної (професійно-технічної) освіти в якості інструментарію можна використати розроблену нами діагностичну анкету професійно-педагогічної компетентності викладача, яка включає перелік компетентностей, якими повинен володіти педагог у таких компонентах: нормативно-правова компетентність, фахова, психологічна, педагогіко-технологічна, методична, інформаційно-комунікаційна, дослідноекспериментальна, культурологічно-виховна компетентність [9].

\section{VВисновки}

Отже, кваліфікаційне оцінювання $€$ окремою важливою складовою системи неперервного професійного розвитку. Кваліфікаційне оцінювання викладачів закладів професійної (професійнотехнічної) освіти потребує розробки спеціального інструментарію, який би відповідав профілю професійно-педагогічної діяльності викладача, що і є перспективою подальших розвідок.

\section{Бібліограффічні посилання}

[1] Джантіміров А. Ю. Багаторівнева підготовка інженерно-педагогічних кадрів для професійно-технічних навчальних закладів [Текст] : дис... канд. пед. наук: 13.00.04; Ін-т пед. освіти і освіти дорослих АПН України. К., 2007. 275 с.

[2] Енциклопедія освіти / Академія пед. наук України ; головний редактор В.Г. Кремінь. К. : Юрінком Інтер, 2008. 1040 с.

[3] Закон України "Про освіту". URL: http://zakon2.rada.gov.ua/laws/show/2145-19 (дата звернення 10.12.2018).

[4] Закон України "Про технічні регламенти та оцінку відповідності“. URL: http://zakon2.rada.gov.ua/laws/show/124-19 (дата звернення 10.12.2018).

[5] Кривоніс M. Сертифікація вчителів США як засіб удосконалення якості профресійної освіти. URL: http://ena.lp.edu.ua/bitstream/ntb/24057/1/30-242-248.pdf (дата звернення 20.12.2018).

[6] Лунячек В. E. Професійний розвиток вчителя: нові можливості, які відкриває Закон України «Про освіту». URL: http://education-ua. org/ua/articles/1085-profesijnij-rozvitok-vchitelya-novimozhlivosti-yaki-vidkrivae-zakon-ukrajini-pro-osvitu (дата звернення 25.12.2018)

[7] Огієнко О. Профресійна підготовка вчителів у Великій Британії, Франції, Канаді і США: подібне та відмінне. URL: http://lib.iitta.gov.ua/706154/1/\%D0\%9E\%D0\%9B\%D0\%95\%D0\%9D\%D0\%90\%20\%D0\%9E\%D0\%93\%D0\%86\%D0\%84\%D 0\%9D\%D0\%9A\%D0\%9E\%D1\%81\%D1\%82\%D0\%B0\%D1\%82\%D1\%82\%D1\%8F.pdf (дата звернення 20.12.2018)

[8] Проект Положення про сертифікацію педагогічних працівників. URL: https://mon.gov.ua/ua/news/mon-proponuye-dlyagromadskogo-obgovorennya-proekt-polozhennya-pro-sertifikaciyu-pedagogichnih-pracivnikiv (дата звернення 10.12.2018).

[9] Сиско Н. М. Діагностика як засіб планування професійного розвитку викладача закладу професійної (профресійнотехнічної) освіти / Науковий вісник Мелітопольського держ. пед. ун-ту, 2017. №2. С. 186-196.

[10] Словник іншомовних слів ; за ред. О.С. Мельничука. Київ : Головна редакція "Українська радянська енциклопедія", 1974. $776 \mathrm{c}$.

[11] Термінологічний словник з основ підготовки наукових та науково-педагогічних кадрів післядипломної педагогічної освіти (2014) / авт. кол.: Є.Р. Чернишова, Н.В. Гузій, В.П. Ляхоцький [та ін.] ; за наук. ред. Є.Р. Чернишової; Держ. вищ. навч. заклад "Ун-т менедж. освіти”. К. : ДВНЗ Університет менеджменту освіти”, 2014. 230 с.

[12] Типове положення про атестацію педагогічних працівників України. URL: http://zakon0.rada.gov.ua/laws/show/z0176-93 (дата звернення 10.12.2018).

[13] Типове положення про атестацію педагогічних працівників. URL: http://zakon2.rada.gov.ua/laws/show/z1255-10 (дата звернення 10.12.2018).

[14] Ткачук T. Потрібна сертифікація освітян / Освітня політика: портал громадських експертів. URL: http://educationua.org/ua/articles/329-potribna-sertifikatsiya-osvityan (дата звернення 10.12.2018).

[15] У 2019 році 1 тис вчителів початкових класів за бажанням зможуть пройти сертифікацію та отримати 20\% надбавку до зарплати, реєстрація почнеться 15 січня - рішення Уряду. URL: https://pedpresa.ua/196684-u-2019-rotsi-1-tysvchyteliv-pochatkovyh-klasiv-za-bazhannyam-zmozhut-projty-sertyfikatsiyu-ta-otrymaty-20-nadbavku-do-zarplatyreyestratsiya-pochnetsya-15-sichnya-rishennya-uryadu.html (дата звернення 20.12.2018).

[16] Шевчук Л. І. Зовнішнє незалежне підтвердження кваліфікації педагогів професійної освіти / Професійно-технічна освіта, 2016. № 1. С.21-23.

[17] Юридичний словник. URL: http://kodeksy.com.ua/dictionary/s/sertifikatsiya.htm (дата звернення 10.12.2018).

[18] Graham P. A. Schooling America: How the Public Schools Meet the Nation's Changing Needs / P. A. Graham. - New York : Oxford University Press, Inc., 2005. -273 p.

[19] Stecher B. M. Using Alternative Assessments in Vocational Education / B. M. Stecher, M. Rahn, A. Ruby, M. Alt, A. Robyn, B. Ward. - RAND, 1997. - 193 p. 
[20] Teacher Education Policy in the United States: Issues and Tensions in an Era of Evolving Expectations / Edited by Penelope M. Earley, David G. Imig \& Nicholas M. Michelli. - New York, NY: Taylor \& Francis Routledge, 2011. - 272 p.

\section{References}

[1] Dzhantimirov, A.lu (2007). Bahatorivneva pidhotovka inzhenerno-pedahohichnykh kadriv dlia profesiino-tekhnichnykh navchalnykh zakladiv [Multi-level training of engineering and pedagogical staff for vocational schools] (Dys. kand. ped. nauk). The Institute for Pedagogical Education and Adult Education of The National Academy of Pedagogical Sciences of Ukraine, Kyiv. [in Ukrainian]

[2] Kremin, V.H. (Ed.) (2018). Entsyklopediia osvity [Encyclopedia of Education] (2008). Akademiia ped. nauk Ukrainy, Yurinkom Inter, Kyiv, Ukraina, 1040. [in Ukrainian]

[3] (2018). Zakon Ukrainy "Pro osvitu" [The Law of Ukraine "On Education"]. URL: http://zakon2.rada.gov.ua/laws/show/2145-19 (accessed 10.12.2018) [in Ukrainian].

[4] (2018). Zakon Ukrainy "Pro tekhnichni rehlamenty ta otsinku vidpovidnosti“. [Law of Ukraine "On Technical Regulations and Conformity Assessment"]. URL: http://zakon2.rada.gov.ua/laws/show/124-19 (accessed 10.10.2018) [in Ukrainian].

[5] Kryvonis, M. (2012). Certyfikatsiia vchyteliv SShA yak zasib udoskonalennia yakosti profesiinoi osvity. [Certification of US Teachers as a means of improving the quality of vocational educatio]. URL: http://ena.Ip.edu.ua/bitstream/ntb/24057/1/30242-248.pdf. (accessed 20.12.2018) [in Ukrainian].

[6] Luniachek, V. E. (2017). Profesiinyi rozvytok vchytelia: novi mozhlyvosti, yaki vidkryvaie Zakon Ukrainy «Pro osvitu». [Teacher Professional Development: New Opportunities Opened by the Law of Ukraine "On Education"]. URL: http://education-ua.org/ua/articles/1085-profesijnij-rozvitok-vchitelya-novimozhlivosti-yaki-vidkrivae-zakon-ukrajini-pro-osvitu (accessed 20.12.2018) [in Ukrainian].

[7] Ohiienko, O. I. (2016). Profesiina pidhotovka vchyteliv u Velykii Brytanii, Frantsii, Kanadi i SShA: podibne ta vidminne [Teacher training in Great Britain, France, Canada and the United States: similar and excellent]. URL:: http://lib.itta.gov.ua/706154/1/\%D0\%9E\%D0\%9B\%D0\%95\%D0\%9D\%D0\%90\%20\%D0\%9E\%D0\%93\%D0\%86\%D0\%84\%D 0\%9D\%D0\%9A\%D0\%9E\%D1\%81\%D1\%82\%D0\%B0\%D1\%82\%D1\%82\%D1\%8F.pdf (accessed 20.12.2018) [in Ukrainian].

[8] Proekt Polozhennia pro sertyfikatsiiu pedahohichnykh pratsivnyki. [Draft Regulations on the Certification of Teachers]. URL: https://mon.gov.ua/ua/news/mon-proponuye-dlya-gromadskogo-obgovorennya-proekt-polozhennya-pro-sertifikaciyupedagogichnih-pracivnikiv (accessed 10.12.2018) [in Ukrainian].

[9] Sysko, N. M. (2017). Diahnostyka yak zasib planuvannia profesiinoho rozvytku vykladacha zakladu profesiinoi (profesiinotekhnichnoi) osvity [Diagnostics as a means of planning professional development of a teacher of vocational (vocational) education]. Naukovyi visnyk Melitopolskoho derzh. ped. un-tu, 2 (19), 186-196. [in Ukrainian].

[10] Melnychuk, O.S. (Ed.) (1974). Slovnyk inshomovnykh sliv. [Dictionary of foreign words]. Holovna redaktsiia "Ukrainska radianska entsyklopediia", Kyiv, Ukraine, 776. [in Ukrainian].

[11] Chernyshova, Ye.R. (Ed.), Huzii, N.V., Liakhotskyi, V.P., ets. (2014). Terminolohichnyi slovnyk z osnov pidhotovky naukovykh ta naukovo-pedahohichnykh kadriv pisliadyplomnoi pedahohichnoi osvity [Terminological dictionary on the basics of preparation of scientific and scientific-pedagogical staff of postgraduate pedagogical education]. DVNZ Universytet menedzhmentu osvity", Kyiv, Ukraine, 230. [in Ukrainian].

[12] (1993). Typove polozhennia pro atestatsiiu pedahohichnykh pratsivnykiv Ukrainy. [Typical position on attestation of pedagogical workers of Ukraine]. URL: http://zakon0.rada.gov.ua/laws/show/z0176-93 (accessed 10.12.2018) [in Ukrainian].

[13] (2010). Typove polozhennia pro atestatsiiu pedahohichnykh pratsivnykiv. [Typical position on attestation of pedagogical workers]. URL: http://zakon2.rada.gov.ua/laws/show/z1255-10 (accessed 10.12.2018). [in Ukrainian].

[14] Tkachuk, T. (2015). Potribna sertyfikatsiia osvitian Osvitnia polityka: portal hromadskykh ekspertiv. [Certification of educators is required]. URL: http://education-ua.org/ua/articles/329-potribna-sertifikatsiya-osvityan (accessed 10.12.2018). [in Ukrainian].

[15] (2018). U 2019 rotsi 1 tys vchyteliv pochatkovykh klasiv za bazhanniam zmozhut proity sertyfikatsiiu ta otrymaty $20 \%$ nadbavku do zarplaty, reiestratsiia pochnetsia 15 sichnia - rishennia Uriadu. [In 2019, 1,000 primary school teachers will be able to obtain certification if they wish and receive a $20 \%$ increase in salary, starting on January 15 - the Government's decision]. URL: https://pedpresa.ua/196684-u-2019-rotsi-1-tys-vchyteliv-pochatkovyh-klasiv-za-bazhannyam-zmozhut-projtysertyfikatsiyu-ta-otrymaty-20-nadbavku-do-zarplaty-reyestratsiya-pochnetsya-15-sichnya-rishennya-uryadu.html (accessed 20.12.2018) [in Ukrainian].

[16] Shevchuk, L. I. (2016). Zovnishnie nezalezhne pidtverdzhennia kvalifikatsii pedahohiv profesiinoi osvity. [External independent confirmation of professional qualifications of teachers of vocational education]. Profesiino-tekhnichna osvita, 1 , 21-23. [in Ukrainian].

[17] (2018). lurydychnyi slovnyk. [Legal dictionary]. URL:http://kodeksy.com.ua/dictionary/s/sertifikatsiya.htm (accessed 10.12.2018). [in Ukrainian].

[18] Graham, P. A. (2005). Schooling America: How the Public Schools Meet the Nation's Changing Needs. Oxford University Press Inc., New York, USA, 273.

[19] Stecher, B. M., Rahn, M., Ruby, A., Alt, M., Robyn, A., Ward, B. (1997). Using Alternative Assessments in Vocational Education. RAND, 193.

[20] Earley, Penelope M. (Ed.), Imig, David G. (Ed.), Michelli, Nicholas M. (Ed.) (2011). Teacher Education Policy in the United States: Issues and Tensions in an Era of Evolving Expectations. Taylor \& Francis Routledge, New York, USA, 272. 


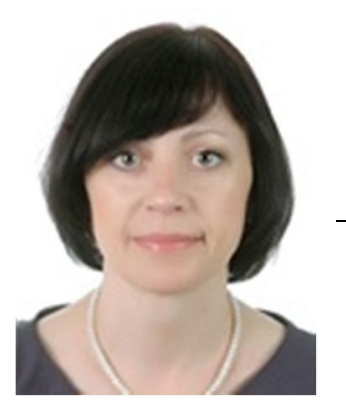

\section{Сиско Наталія Миколаївна,}

кандидат психологічних наук, докторант,

Інститут педагогічної освіти і освіти дорослих імені Івана Зязюна НАПН України,

вул. Максима Берлінського, 9, Київ, Україна, 04060

Тел. 067-2-756-756. E-mail: nnsysko@ukr.net

Sysko Nataliia Mukolaivna,

$\mathrm{PhD}$ in Psychology, Postdoctoral Researcher,

Ivan Zyazyun Institute of Pedagogical and Adult Education NAES of Ukraine

Maxim Berlinsky str., 9, Kiev, Ukraine, 04060

Tel. 067-2-756-756. E-mail: nnsysko@ukr.net

ORCID: orcid.org/0000-0001-7665-8325

\section{Citation (APA):}

Sysko, N. (2018). Qualification evaluation of the results of teachers' professional development which work in the professional (vocational) education institutions. Engineering and Educational Technologies, 6 (4), 17-29. doi: https://doi.org/10.30929/23079770.2018.06.04.02

\section{Цитування (ДСТУ 8302:2015):}

Сиско Н. М. Кваліфікаційне оцінювання результатів професійного розвитку викладачів закладів професійної (професійнотехнічної) освіти / Інженерні та освітні технології. 2018. Т. 6. № 4. С. 17-29. doi: https://doi.org/10.30929/2307-

9770.2018 .06 .04 .02

.0бсяг статmі: сторінок-13; умовних друк. аркушів - 1,494. 